\title{
Will Senior Employees Be Willing to Voluntarily Transfer Their Knowledge to Younger Employees? The Effect of Perceived Age Discrimination and Organizational Identification
}

\author{
Fiona Huang \\ Department of Management, City University of Hong Kong, Hong Kong, China \\ Email: shiqhuang4-c@my.cityu.edu.hk
}

How to cite this paper: Huang, F. (2019) Will Senior Employees Be Willing to Voluntarily Transfer Their Knowledge to Younger Employees? The Effect of Perceived Age Discrimination and Organizational Identification. Journal of Human Resource and Sustainability Studies, 7, 244-260.

https://doi.org/10.4236/jhrss.2019.72015

Received: April 22, 2019

Accepted: June 11, 2019

Published: June 14, 2019

Copyright $\odot 2019$ by author(s) and Scientific Research Publishing Inc. This work is licensed under the Creative Commons Attribution International License (CC BY 4.0).

http://creativecommons.org/licenses/by/4.0/

\begin{abstract}
This research focuses on the important issues of age discrimination and intergenerational knowledge transfer. Through online questionnaire method, where 291 effective responses were acquired, this research found that perceived age discrimination by senior employees was negatively related to their intention to transfer their knowledge to younger employees. This negatively effect was fully mediated by organizational identification, where perceived age discrimination was negatively related to organizational identification while organizational identification was positively related to intergenerational knowledge transfer intention. This research made theoretical contribution by linking the two important issues, age discrimination and intergenerational knowledge transfer, as well as by identifying the underlying mechanism for this linkage. The research would hopefully help manager in workplace to encourage senior employees to transfer knowledge to younger employees, by providing a more respectful workplace for senior employees.
\end{abstract}

\section{Keywords}

Perceived Age Discrimination, Organizational Identification, Intergenerational Knowledge Transfer Intention

\section{Introduction}

The world seems to face most severe talent shortage since financial crisis in 2008 
[1] [2]. Among 42,300 global employers surveyed, 40\% expressed that they are faced with talent shortages [1]. A common strategy dealing with the current talent shortage problem is to strengthen talent pool [3]. Since talent demand is increasing and talent pool is shrinking, it would be more and more expensive to buy talent from outside the organization. Plus, organizational loyalty and cultural fit would also be problems of hiring talent externally [4]. Thus it becomes essential to think of developing the talent pool from inside the organization. Talent pool development is associated with identifying future business knowledge needs and resonates with secession planning [5]. In line with talent pool development is to see knowledge needed by young workers and to encourage older workers to pass knowledge to young workers in advance. This calls for the emphasis on intergenerational knowledge transfer.

Knowledge transferring, as a way to pass wisdom of old employees to young employees, would help organization to prevent the talent pool from going dry. However, it is a rather altruistic act because it is the contribution from old employees to the benefit of other people in the organization [4]. Therefore, how to make old employees willing to share knowledge and experience with young employees, will be an important issue to address. As [6] stated, the field of knowledge transfer from older and retiring workers to younger workers has been rarely studied. This is the reason why this research is going to explore to what degree old employees are willing to share knowledge, and whether this knowledge sharing intention is discouraged by age discrimination.

Moreover, age discrimination has long been a severe problem. In the United States, over $1 / 4$ of total population are predicted to demonstrate age discrimination over older people, according to a social survey in US [7]. In China, many individuals are holding negative biased views on older people as well, considering them as lonely, upset, and weak in physical status as prejudgment [7]. According to a survey among younger individuals in China, around $21 \%$ of them are holding negative cognition towards older people, and $23.8 \%$ of them are holding negative emotion towards older people [8].

Right now the topic of severe age discrimination has not been linked together to see how age discrimination harms older talent management. Because of research gap in intergenrational knowledge transfer, and because of severe age discrimination problem in both western and eastern countries, this study plan to answer the question of how age discrimination will hinder intergenerational knowledge transfer.

This research aims to look into knowledge transfer as a way to solve talent shortage, and to fill the research gap of the relationship between age discrimination and knowledge transfer. This aim will help understanding of the relationship between age discrimination and intergenerational knowledge transferring, as well as responding to the talent shortage problem and talent pool development. 


\section{Literature Review}

\subsection{Age Discrimination}

Age discrimination refers to unfair perceptions and unfair treatment of any age group because they are too young or too old [9]. However, when the research is focusing on older workers, age discrimination commonly refers to unfair perceptions and unfair treatment of older employees for being too old [10].

According to a research, UK Citizenship Survey, employees can feel discriminated in many aspects, such as age, race, and gender, among which age discrimination is most frequently perceived by employees [11]. UK is not the only case. In China age discrimination is a severe problem as well. According to [12] and [13], residential status, gender, and age are the three most significant discrimination sources in China now.

Age discrimination is hindering achievements of organizations [10]. Perceived age discrimination is negatively related to organizational performance [9]. This implies the importance for organizations to promote fair perceptions and fair treatment of all age groups, and prevent age discrimination [14]. Moreover, age discrimination will have negative social impact as well. In China employees may be laid off and forced to early retirement because of age discrimination. Then it will be hard for them to rejoin the labor force, due to biased perception on older age [15]. This can cause a loss of older talents in organization. Therefore, to study age discrimination in China is also of great practical value.

\subsection{Organizational Identification}

Organizational identification refers to "a perceived oneness with an organization and the experience of the organization s successes and failures as one's own" [16], which is important to the well-being of employees and the organizations. Organizational identification is associated with the self-concept of employees cognitively or emotionally.

With higher organizational identification, employees are more willing to voluntarily contribute to the organization and help other employees. In this research, since voluntary knowledge transfer is investigated, it is logical to link higher organizational identification with higher intention of intergenerational knowledge transfer intention.

\subsection{Intergenerational Knowledge Transfer (IGKT)}

Knowledge transfer is useful in dealing with talent shortage in organizations resulting from older employee's retirement and lack of replacement of large and knowledgeable cohort of employees. Knowledge transfer is described as "passing knowledge from one person to others or to the broader organizational knowledge base" [4]. It is important because knowledge cannot be fully recovered once it is lost. Thus organizations should capture knowledge before it diminishes.

Intergenerational knowledge transfer is defined as "knowledge transfer from 
older to younger employees" [17] [18] [19]. This requires the action of knowledge transfer from older employees to younger employees [4]. Knowledge transfer from older employees to younger employees is a rather voluntary behavior, because older employees are helping other people or the organization to accumulate knowledge, mostly without explicit compensation.

\section{Hypotheses and Model}

In the context of older employer research, perceived age discrimination can be limited to the unfair perception of older employees for being too old [10]. Yet unfair perception in organizations can impede OCB (individual behavior that is discretionary, not directly or explicitly recognized by the formal reward system, and that in the aggregate promotes the effective functioning of the organization) [20] [21] [22]. Previous research demonstrates empirical evidence for discriminations in organization to hinder OCB [23]. Since knowledge transfer is altruistic [4], and is a voluntary arrangement that involve exchange, sharing, or co-development [24], the research proposes hypothesis 1 :

H1: Perceived age discrimination is negatively related to IGKTI.

The traditional social identity theory focuses mainly on the cognitive part of social identity, and the evaluative component did not attracted much research attention [25]. According to social identity theory, employees' identification with organizations are not only affected by their comparison of their organizations with other organizations, but also influenced by how they are evaluated by other employees [25] [26]. Since age discrimination is "unfair perceptions and unfair treatment of older employees for being too old" [10], and thus is associated with unfair evaluation, it is hypothesized that age discrimination will negatively influence senior employees' identification with organizations. Thus the research proposes hypothesis 2 :

H2: Age discrimination perceived by senior employees is negatively related to their organizational identity.

Also according to social identity theory, people's cooperative behavior in the group, particularly that which is discretionary in nature, comes from their organizational identification (Tyler and Blader, 2000; Tyler, 2012) [25] [27]. In this research, since it is investigated how willing senior employees are to voluntarily transfer their knowledge to younger employees, and the key variable IGKTI is treated as discretionary, it is proposed that organizational identification will be positively related to IGKTI. Thus the research proposes hypothesis 3, together with hypothesis 4 which is logically based on hypotheses 1,2 , and 3 :

H3: Senior employees' organizational identity is positively related to their IGKTI.

H4: Senior employees' organizational identity mediates the relationship between perceived age discrimination and IGKTI.

With the above hypotheses, the research develops the following model (Figure $1)$ : 


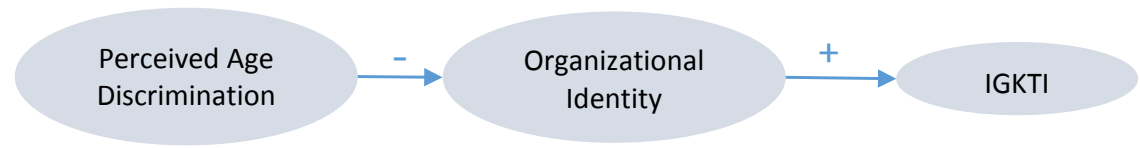

Figure 1. Research Model ("IGKTI" stands for intergenerational knowledge transfer intention).

Based on this model, the research will investigate the relationship between perceived age discrimination, organizational identity and IGKTI.

To verify the hypotheses, the research collected data through online questionnaire, and used SPSS software to conduct correlation analysis as well as regression analysis for the data.

\section{Methodology}

This research uses quantitative method instead of qualitative method. As [19] stated, current studies in intergenerational knowledge transfer are qualitative and with little empirical evidence. There are some studies working on intergenerational knowledge transfer finding organizational antecedents for it, such as intergenerational supportive climate, top management support, and organizational institution. However, until the investigation of [19], hardly there are study findings to empirically verify the relationships between these organizational factors and younger employees' participation in intergenerational knowledge transfer. Thus, this study aims to fill this vain, by using empirical quantitative method. Specifically, this research will use online questionnaire.

\subsection{Data Collection}

To distinguish senior employees from other employees, I followed the criteria from [10] and used the criterion of 45 years old, considering employees who are 45 years old or older as senior employees. I conducted an online survey with Chinese working adults who are 45 or older. In line with other published researches [28] [29] [30], this research used a survey platform, SoJump, which is a web-based research institute and provides services for respondent recruitment and data collection. I collected questionnaire data from 310 participants. After eliminating ineffective data, there are 291 usable responses. The effective response rate is $93.87 \%$.

Of the final sample (see Table 1), $43.30 \%$ were female and $56.70 \%$ were male, and age of all respondents ranged from 45 to 59 years old. $65.64 \%$ of respondents had a university degree or above. 151 of the 291 respondents $(51.89 \%$ of all respondents) are from state-owned organizations or government, with another 140 respondents (48.11\% of all respondents) from non-state-owned organizations. The range of organizational tenure is from 1 year to 37 years, with an average of 19 years. $79.38 \%$ of respondents are supervisors (any kinds of supervisors from low-level, middle-level to high-level) in the organization, while $20.62 \%$ of respondents are not supervisors. 
Table 1. Table of sample characteristics.

\begin{tabular}{|c|c|c|c|}
\hline & & $\begin{array}{l}\text { Number of effective } \\
\text { respondents }\end{array}$ & Percentage \\
\hline \multirow{2}{*}{ Gender } & Male & 165 & $56.70 \%$ \\
\hline & Female & 126 & $43.30 \%$ \\
\hline \multirow{5}{*}{ Education } & $\begin{array}{l}\text { High school/secondary } \\
\text { technical school and below }\end{array}$ & 14 & $4.81 \%$ \\
\hline & Junior professional college & 86 & $29.55 \%$ \\
\hline & Bachelor & 157 & $53.95 \%$ \\
\hline & Master's degree & 28 & $9.62 \%$ \\
\hline & $\mathrm{PhD}$ degree or above & 6 & $2.06 \%$ \\
\hline \multirow{4}{*}{ Age } & $45-49$ & 277 & $95.19 \%$ \\
\hline & $50-54$ & 11 & $3.78 \%$ \\
\hline & $55-59$ & 3 & $1.03 \%$ \\
\hline & $1-10$ & 35 & $12.03 \%$ \\
\hline \multirow{3}{*}{$\begin{array}{l}\text { Organizational } \\
\text { Tenure (in years) }\end{array}$} & $11-20$ & 120 & $41.24 \%$ \\
\hline & $21-30$ & 131 & $45.01 \%$ \\
\hline & $31-40$ & 5 & $1.72 \%$ \\
\hline \multirow{2}{*}{ Supervisory } & Supervisory & 231 & $79.38 \%$ \\
\hline & Non-supervisory & 60 & $20.62 \%$ \\
\hline \multirow[t]{2}{*}{ Company type } & State-owned organizations & 151 & $51.89 \%$ \\
\hline & Non-state-owned organizations & 140 & $48.11 \%$ \\
\hline
\end{tabular}

Note: Total effective $\mathrm{N}=291$.

\subsection{Measurement}

Since all of our respondents were Chinese, I translate the original scales following the back-translation procedure recommended by [31]. Participants were informed of confidentiality of their answers, with explicit expression on the questionnaire that "All your answers will be confidential. They will not be presented to anyone in your organization. They will not be used for business purpose". All items of age discrimination, organizational identification, and IGKTI and measured with a 7 -point Likert type scale ( $1=$ strongly disagree; $7=$ strongly agree).

For perceived age discrimination, I used the most commonly-used scale from [10], asking 6 questions about to what degree older employees feel that they are discriminated in the organization (Appendix). A sample item is "I have sometimes been unfairly singled out because of my age". The Cronbach alpha is 0.82 as reported by [10].

Organization identification was measured with 6 items developed by [16]. A sample item is "This organization's successes are my successes" (Appendix). The Cronbach alpha is 0.79 as reported by [16].

For intergenerational knowledge transfer intention, this research adapts [32]'s 5-item questionnaire (Appendix). This measurement is consistent with other 
researches studying knowledge sharing intention [33] [34] and IGKTI [19] [35]. The 5 items measure 2 dimensions of respondents' intention to share explicit knowledge and intention to share implicit knowledge. Because this scale measures the knowledge sharing intention for general respondents, I adjusted it to fit more closely with our topic of "intergenerational knowledge transfer intention". I changed words "members" to "younger employees" in every item, aiming to measure the extent to which senior employees would intend to share their knowledge with younger employees. A sample item is "I will always provide my manuals, methodologies and models for younger employees of my organization". The Cronbach alpha of this scale is 0.83 as reported by [32].

\subsection{Data Analysis}

After data collection from 300 participants, the research will get values of 3 key variables: perceived age discrimination, organizational identification, and IGKTI.

To test the two mediation effects, the research will first follow [36]'s procedure. With this method, three conditions should be satisfied to support a mediation effect $(\mathrm{X} \rightarrow \mathrm{M} \rightarrow \mathrm{Y}$ ) (for the effect of perceived age discrimination $\rightarrow$ organizational identification $\rightarrow$ IGKTI): 1) perceived age discrimination has a significant effect on IGKTI, 2) perceived age discrimination has a significant effect on organizational identification, and 3) organizational identification has a significant effect on IGKTI after accounting for the effect of perceived age discrimination, whereas the effect of perceived age discrimination on IGKTI becomes less or non-significant.

\section{Results}

Table 2 shows the descriptive Statistics of primary variables. As can be seen in this table, the average year is 46 years old, while average organizational tenure is 19 years. All 291 effective respondents are not retired and work full-time now. Most of the respondents are working as a supervisor role (team leader, manager, or executives, etc.) in the organization. Around half of the effective respondents are from state-owned organizations, while the other half is from non-state-owned organizations.

Table 3 shows the correlations among primary variables. As can be seen from Table 3, several factors are related to perceived age discrimination. The correlation between gender and perceived age discrimination is significant $(\beta=-0.141$, $\mathrm{p}<0.05)$, meaning that female are more likely to feel being discriminated by others at work because of age, when compared with male. The correlation between age and perceived age discrimination is marginally significant $(\beta=0.115$, $\mathrm{p}=0.05$ ), demonstrating that older senior employees are more likely to perceive himself/herself as being discriminated by others because of being too old.

In addition, Table 3 also shows that several factors are associated with organizational identification. Being supervisor at work is related with higher level of organizational identification $(\beta=-0.158, \mathrm{p}<0.01)$. In addition, organizational 
type is related with organizational type, in that employees from non-state-owned organizations display higher level of organizational identification, when compared with employees from state-owned organization $(\beta=0.137, \mathrm{p}<0.05)$.

Furthermore, other control variables are related to intergenerational knowledge transfer intention. Surprisingly, people with higher education background is less willing to transfer knowledge intergerationally $(\beta=-0.137, \mathrm{p}<0.05)$. A supervisor at work is more likely to have higher intention of intergenerational knowledge transfer, when compared to a non-supervisor $(\beta=-0.154, \mathrm{p}<0.01)$.

After the descriptive analysis and analysis of correlation among primary variables, we start hypothesis testing as following.

To test hypothesis 1 , we run regression where dependent variable is intergenerational knowledge transfer intention, and independent variable is perceived age discrimination (Table 4, model 1). The result shows that intergenerational knowledge transfer intention is negatively correlated with perceived age discrimination $(\beta=-0.168, \mathrm{p}<0.001)$, when controlling gender, education, age, organizational tenure, being supervisor and organizational type. Thus hypothesis 1 is supported.

Then to test hypothesis 2, we run regression of organizational identification on perceived age discrimination (Table 5, model 2). The result shows that the relationship between perceived age discrimination and organizational identification is negative and significant $(\beta=-0.173, \mathrm{p}<0.001)$, when controlling gender, education, age, organizational tenure, being supervisor and organizational type. Thus hypothesis 2 is supported.

Table 2. Descriptive statistics of primary variables.

\begin{tabular}{cccc}
\hline & Descriptive Statistics & \\
\hline Mean & Std. Deviation & N & 291 \\
education & 1.433 & 0.4963 & 291 \\
age & 2.746 & 0.7772 & 291 \\
org_tenure & 46.086 & 1.9198 & 291 \\
retired & 19.096 & 6.5515 & 291 \\
full-time & 2.000 & 0.0000 & 291 \\
supervisor & 1.000 & 0.0000 & 291 \\
company_type & 1.206 & 0.4053 & 291 \\
ad & 1.481 & 0.5005 & 291 \\
oi & 3.9525 & 1.18124 & 291 \\
IGKTI & 5.0470 & 0.98586 & 291 \\
\hline
\end{tabular}

Note: Gender: 1 = male, 2 = female. Education: 1 = high school/secondary technical school and below, $2=$ junior professional college, 3 = bachelor, 4 = master's degree, $5=\mathrm{PhD}$ degree or above. Organizational tenure is listed in years. Retired: 1 = retired, 2 = not retired. Full-time: 1 = working full time, 2 = not working full time. Supervisor: 1 = act as supervisory role in the organization (team leader, manager, or executives, etc.), 2 = not a supervisor in the organization. Company type: 1 = state-owned organizations, $2=$ non-state-owned organizations. 
Table 3. Correlations among primary variables.

\begin{tabular}{|c|c|c|c|c|c|c|c|c|c|c|c|c|}
\hline \multicolumn{13}{|c|}{ Correlations } \\
\hline & & gender & education & age & $\begin{array}{l}\text { org } \\
\text { tenure }\end{array}$ & retired & full-time & $\begin{array}{l}\text { super- } \\
\text { visor }\end{array}$ & $\begin{array}{c}\text { company } \\
\text { type }\end{array}$ & ad & oi & IGKTI \\
\hline \multirow{3}{*}{ gender } & $\begin{array}{l}\text { Pearson } \\
\text { Correlation }\end{array}$ & 1 & -0.089 & -0.122 & -0.046 &.$^{\mathrm{a}}$ &.$^{\mathrm{a}}$ & 0.103 & -0.064 & -0.141 & -0.016 & -0.073 \\
\hline & Sig. (2-tailed) & & 0.130 & 0.037 & 0.437 & . & . & 0.079 & 0.276 & 0.016 & 0.788 & 0.212 \\
\hline & $\mathrm{N}$ & 291 & 291 & 291 & 291 & 291 & 291 & 291 & 291 & 291 & 291 & 291 \\
\hline \multirow{3}{*}{ education } & $\begin{array}{l}\text { Pearson } \\
\text { Correlation }\end{array}$ & -0.089 & 1 & 0.054 & 0.017 &.$^{\mathrm{a}}$ &.$^{\mathrm{a}}$ & -0.260 & -0.074 & -0.046 & 0.061 & -0.137 \\
\hline & Sig. (2-tailed) & 0.130 & & 0.359 & 0.773 & . & . & 0.000 & 0.205 & 0.430 & 0.303 & 0.020 \\
\hline & $\mathrm{N}$ & 291 & 291 & 291 & 291 & 291 & 291 & 291 & 291 & 291 & 291 & 291 \\
\hline \multirow{3}{*}{ age } & $\begin{array}{l}\text { Pearson } \\
\text { Correlation }\end{array}$ & -0.122 & 0.054 & 1 & 0.394 &.$^{\mathrm{a}}$ &.$^{\mathrm{a}}$ & -0.041 & -0.058 & 0.115 & 0.012 & -0.029 \\
\hline & Sig. (2-tailed) & 0.037 & 0.359 & & 0.000 & . & . & 0.491 & 0.328 & 0.050 & 0.833 & 0.617 \\
\hline & $\mathrm{N}$ & 291 & 291 & 291 & 291 & 291 & 291 & 291 & 291 & 291 & 291 & 291 \\
\hline \multirow{3}{*}{$\begin{array}{l}\text { org } \\
\text { tenure }\end{array}$} & $\begin{array}{c}\text { Pearson } \\
\text { Correlation }\end{array}$ & -0.046 & 0.017 & 0.394 & 1 &.$^{\mathrm{a}}$ &.$^{\mathrm{a}}$ & 0.093 & -0.281 & 0.029 & 0.089 & 0.050 \\
\hline & Sig. (2-tailed) & 0.437 & 0.773 & 0.000 & & . & . & 0.115 & 0.000 & 0.626 & 0.128 & 0.392 \\
\hline & $\mathrm{N}$ & 291 & 291 & 291 & 291 & 291 & 291 & 291 & 291 & 291 & 291 & 291 \\
\hline \multirow{3}{*}{ retired } & $\begin{array}{l}\text { Pearson } \\
\text { Correlation }\end{array}$ &.$^{\mathrm{a}}$ &.$^{\mathrm{a}}$ &.$^{\mathrm{a}}$ &.$^{\mathrm{a}}$ &.$^{\mathrm{a}}$ &.$^{\mathrm{a}}$ &.$^{\mathrm{a}}$ &.$^{\mathrm{a}}$ &.$^{\mathrm{a}}$ &.$^{\mathrm{a}}$ &.$^{\mathrm{a}}$ \\
\hline & Sig. (2-tailed) & . & . & . & . & & . & . & . & . & . & . \\
\hline & $\mathrm{N}$ & 291 & 291 & 291 & 291 & 291 & 291 & 291 & 291 & 291 & 291 & 291 \\
\hline \multirow{3}{*}{ full-time } & $\begin{array}{l}\text { Pearson } \\
\text { Correlation }\end{array}$ &.$^{\mathrm{a}}$ &.$^{\mathrm{a}}$ &.$^{\mathrm{a}}$ &.$^{\mathrm{a}}$ &.$^{\mathrm{a}}$ &.$^{\mathrm{a}}$ &.$^{\mathrm{a}}$ &.$^{\mathrm{a}}$ &.$^{\mathrm{a}}$ &.$^{\mathrm{a}}$ &.$^{\mathrm{a}}$ \\
\hline & Sig. (2-tailed) & . & . & . & . & . & & . & . & . & . & . \\
\hline & $\mathrm{N}$ & 291 & 291 & 291 & 291 & 291 & 291 & 291 & 291 & 291 & 291 & 291 \\
\hline \multirow{3}{*}{ supervisor } & $\begin{array}{l}\text { Pearson } \\
\text { Correlation }\end{array}$ & 0.103 & -0.260 & -0.041 & 0.093 &.$^{\mathrm{a}}$ &.$^{\mathrm{a}}$ & 1 & -0.134 & 0.093 & -0.158 & -0.154 \\
\hline & Sig. (2-tailed) & 0.079 & 0.000 & 0.491 & 0.115 & . & . & & 0.023 & 0.115 & 0.007 & 0.009 \\
\hline & $\mathrm{N}$ & 291 & 291 & 291 & 291 & 291 & 291 & 291 & 291 & 291 & 291 & 291 \\
\hline \multirow{3}{*}{$\begin{array}{c}\text { company_ } \\
\text { type }\end{array}$} & $\begin{array}{l}\text { Pearson } \\
\text { Correlation }\end{array}$ & -0.064 & -0.074 & -0.058 & -0.281 &.$^{\mathrm{a}}$ &.$^{\mathrm{a}}$ & -0.134 & 1 & 0.059 & 0.137 & -0.015 \\
\hline & Sig. (2-tailed) & 0.276 & 0.205 & 0.328 & 0.000 & . & . & 0.023 & & 0.314 & 0.019 & 0.796 \\
\hline & $\mathrm{N}$ & 291 & 291 & 291 & 291 & 291 & 291 & 291 & 291 & 291 & 291 & 291 \\
\hline \multirow{3}{*}{ ad } & $\begin{array}{l}\text { Pearson } \\
\text { Correlation }\end{array}$ & -0.141 & -0.046 & 0.115 & 0.029 &.$^{\mathrm{a}}$ &.$^{\mathrm{a}}$ & 0.093 & 0.059 & 1 & -0.205 & -0.203 \\
\hline & Sig. (2-tailed) & 0.016 & 0.430 & 0.050 & 0.626 & . & . & 0.115 & 0.314 & & 0.000 & 0.000 \\
\hline & $\mathrm{N}$ & 291 & 291 & 291 & 291 & 291 & 291 & 291 & 291 & 291 & 291 & 291 \\
\hline oi & $\begin{array}{c}\text { Pearson } \\
\text { Correlation }\end{array}$ & -0.016 & 0.061 & 0.012 & 0.089 &.$^{\mathrm{a}}$ &.$^{\mathrm{a}}$ & -0.158 & 0.137 & -0.205 & 1 & 0.557 \\
\hline
\end{tabular}




\section{Continued}

\begin{tabular}{|c|c|c|c|c|c|c|c|c|c|c|c|c|}
\hline & Sig. (2-tailed) & 0.788 & 0.303 & 0.833 & 0.128 & . & & 0.007 & 0.019 & 0.000 & & 0.000 \\
\hline & $\mathrm{N}$ & 291 & 291 & 291 & 291 & 291 & 291 & 291 & 291 & 291 & 291 & 291 \\
\hline \multirow{3}{*}{ IGKTI } & $\begin{array}{c}\text { Pearson } \\
\text { Correlation }\end{array}$ & -0.073 & -0.137 & -0.029 & 0.050 &.$^{a}$ &.$^{\mathrm{a}}$ & -0.154 & -0.015 & -0.203 & 0.557 & 1 \\
\hline & Sig. (2-tailed) & 0.212 & 0.020 & 0.617 & 0.392 & . & . & 0.009 & 0.796 & 0.000 & 0.000 & \\
\hline & $\mathrm{N}$ & 291 & 291 & 291 & 291 & 291 & 291 & 291 & 291 & 291 & 291 & 291 \\
\hline
\end{tabular}

Note: "ad" stands for perceived age discrimination. "oi" stands for organizational identification. "IGKTI" stands for intergenerational knowledge transfer intention. a. Cannot be computed because at least one of the variables is constant.

Table 4. Regression of intergenerational knowledge transfer intention on perceived age discrimination (Model 1).

\begin{tabular}{|c|c|c|c|c|c|c|}
\hline \multicolumn{7}{|c|}{ Coefficients $^{\mathrm{a}}$} \\
\hline & \multirow{2}{*}{ Model } & \multicolumn{2}{|c|}{ Unstandardized Coefficients } & \multirow{2}{*}{$\begin{array}{c}\begin{array}{c}\text { Standardized } \\
\text { Coefficients }\end{array} \\
\text { Beta }\end{array}$} & \multirow{2}{*}{$\mathrm{t}$} & \multirow{2}{*}{ Sig. } \\
\hline & & $\mathrm{B}$ & Std. Error & & & \\
\hline \multirow{8}{*}{1} & (Constant) & 8.564 & 1.443 & & 5.936 & 0.000 \\
\hline & gender & -0.205 & 0.112 & -0.105 & -1.829 & 0.068 \\
\hline & education & -0.257 & 0.073 & -0.206 & -3.523 & 0.000 \\
\hline & age & -0.025 & 0.031 & -0.050 & -0.811 & 0.418 \\
\hline & org_tenure & 0.012 & 0.009 & 0.084 & 1.318 & 0.189 \\
\hline & supervisor & -0.457 & 0.142 & -0.192 & -3.222 & 0.001 \\
\hline & company_type & -0.058 & 0.115 & -0.030 & -0.507 & 0.613 \\
\hline & ad & -0.168 & 0.047 & -0.205 & -3.572 & 0.000 \\
\hline
\end{tabular}

a. Dependent Variable: IGKTI.

Table 5. Regression of organizational identification on perceived age discrimination (Model 2).

\begin{tabular}{|c|c|c|c|c|c|c|}
\hline \multicolumn{7}{|c|}{ Coefficients $^{\mathrm{a}}$} \\
\hline & \multirow{2}{*}{ Model } & \multicolumn{2}{|c|}{ Unstandardized Coefficients } & \multirow{2}{*}{$\begin{array}{c}\begin{array}{c}\text { Standardized } \\
\text { Coefficients }\end{array} \\
\text { Beta }\end{array}$} & \multirow{2}{*}{$\mathrm{t}$} & \multirow{2}{*}{ Sig. } \\
\hline & & B & Std. Error & & & \\
\hline \multirow{8}{*}{1} & (Constant) & 5.669 & 1.480 & & 3.830 & 0.000 \\
\hline & gender & -0.028 & 0.115 & -0.014 & -0.242 & 0.809 \\
\hline & education & 0.038 & 0.075 & 0.030 & 0.510 & 0.610 \\
\hline & age & -0.014 & 0.032 & -0.027 & -0.440 & 0.660 \\
\hline & org_tenure & 0.025 & 0.010 & 0.167 & 2.601 & 0.010 \\
\hline & supervisor & -0.297 & 0.145 & -0.122 & -2.044 & 0.042 \\
\hline & company_type & 0.353 & 0.118 & 0.179 & 3.004 & 0.003 \\
\hline & ad & -0.173 & 0.048 & -0.207 & -3.582 & 0.000 \\
\hline
\end{tabular}

a. Dependent Variable: oi 
Then to test hypothesis 3, we run regression where dependent variable is intergenerational knowledge transfer intention and independent variable is organizational identification (Table 6, model 3). The result shows that the relationship between organizational identification and intergenerational knowledge transfer intention is positive and significant $(\beta=0.557, \mathrm{p}<0.001)$, when controlling gender, education, age, organizational tenure, being supervisor and organizational type. Thus hypothesis 3 is supported.

To test hypothesis 4, we run regression of intergenerational knowledge transfer intention on perceived age discrimination and organizational identification, when controlling gender, education, age, organizational tenure, being supervisor and organizational type (Table 7, model 4), and compare the result with that of model 1. From Table 7 (model 4), we can see that the coefficient of perceived age discrimination is nonsignificant $(\beta=-0.075, \mathrm{~ns})$, while the coefficient of organizational identification is positive and significant $(\beta=0.539, \mathrm{p}<0.001)$. That is to say, originally in model 1 , the effect from perceived age discrimination on intergenerational knowledge transfer intention is negative and significant, if merely age discrimination is considered as independent variable. However, in model 4, if adding organizational identification as mediator, the original effect from perceived age discrimination will become insignificant, and the effect from mediator (organizational identification) to dependent variable (intergenerational knowledge transfer intention) is significant and positive as hypothesized. Thus hypothesis 4 is supported. That is to say, organizational identification plays a full mediating role in the relationship between perceived age discrimination and intergenerational knowledge transfer intention.

Table 6. Regression of intergenerational knowledge transfer intention on organizational identification (Model 3).

\begin{tabular}{|c|c|c|c|c|c|}
\hline \multicolumn{6}{|c|}{ Coefficients $^{\mathrm{a}}$} \\
\hline \multirow[t]{2}{*}{ Model } & \multicolumn{2}{|c|}{$\begin{array}{l}\text { Unstandardized } \\
\text { Coefficients }\end{array}$} & \multirow{2}{*}{$\begin{array}{c}\begin{array}{c}\text { Standardized } \\
\text { Coefficients }\end{array} \\
\text { Beta }\end{array}$} & \multirow[t]{2}{*}{$\mathrm{t}$} & \multirow[t]{2}{*}{ Sig. } \\
\hline & $\mathrm{B}$ & Std. Error & & & \\
\hline (Constant) & 5.351 & 1.238 & & 4.323 & 0.000 \\
\hline gender & -0.166 & 0.093 & -0.085 & -1.782 & 0.076 \\
\hline education & -0.275 & 0.061 & -0.221 & -4.495 & 0.000 \\
\hline age & -0.022 & 0.026 & -0.045 & -0.862 & 0.389 \\
\hline org_tenure & -0.001 & 0.008 & -0.010 & -0.177 & 0.860 \\
\hline supervisor & -0.315 & 0.119 & -0.132 & -2.637 & 0.009 \\
\hline company_type & -0.266 & 0.097 & -0.138 & -2.738 & 0.007 \\
\hline oi & 0.557 & 0.048 & 0.569 & 11.727 & 0.000 \\
\hline
\end{tabular}

a. Dependent Variable: IGKTI. 
Table 7. Regression of intergenerational knowledge transfer intention on perceived age discrimination and organizational identification (Model 4).

\begin{tabular}{cccccc}
\hline \multicolumn{5}{c}{ Coefficients $^{\mathrm{a}}$} \\
\hline \multirow{2}{*}{ Model } & \multicolumn{2}{c}{$\begin{array}{c}\text { Unstandardized } \\
\text { Coefficients }\end{array}$} & $\begin{array}{c}\text { Standardized } \\
\text { Coefficients }\end{array}$ & $\mathrm{t}$ & Sig. \\
\cline { 2 - 4 } & B & Std. Error & Beta & & \\
\hline \multirow{2}{*}{ (Constant) } & 5.511 & 1.235 & & 4.461 & 0.000 \\
gender & -0.190 & 0.093 & -0.097 & -2.030 & 0.043 \\
education & -0.277 & 0.061 & -0.223 & -4.555 & 0.000 \\
age & -0.018 & 0.026 & -0.035 & -0.680 & 0.497 \\
org_tenure & -0.001 & 0.008 & -0.008 & -0.141 & 0.888 \\
supervisor & -0.297 & 0.119 & -0.124 & -2.488 & 0.013 \\
company_type & -0.249 & 0.097 & -0.129 & -2.554 & 0.011 \\
ad & -0.075 & 0.040 & -0.091 & -1.866 & 0.063 \\
oi & 0.539 & 0.048 & 0.549 & 11.132 & 0.000 \\
\hline
\end{tabular}

a. Dependent Variable: IGKTI.

\section{Discussion}

This research used questionnaire method to find that perceived age discrimination by focal senior employees will lead to their lower organizational identification, and in turn decrease their intention to transfer their knowledge to younger employees. Organizational identification plays a full mediating role in the negative relationship between perceived age discrimination and intergenerational knowledge transfer intention.

\subsection{Theoretical Contribution}

Both age discrimination and intergenerational knowledge transfer are important topics, but there are seldom researches to study them together and to find out the relationship between them, as well as the mechanism affecting the relationship. Since age discrimination may lead to lower organizational performance [9] [10], it plays an important role in organizational research. In addition, since intergenerational knowledge transfer is mostly voluntary, it is highly linked to the topic of organizational citizenship behavior (OCB). Our study contributes theoretically to found negative relationship between perceived age discrimination and intergenerational knowledge transfer intention, and to find the full mediating effect of organizational identification in this relationship. Our study will also add to the current literature of $\mathrm{OCB}$, because intergenerational knowledge transfer is a rather voluntary and discretionary behavior.

\subsection{Practical Implications}

Facing severe problem of talent shortage in workplace, managers will be provided insight by this research to deal with this problem. Since there are talent shortage problem all over the world and it is hard to recruit talent from outside 
the organization, managers could consider filling the talent pipeline from inside the organization. One way to solve this talent shortage problem is to encourage senior employees to transfer their knowledge to younger employees. Yet this research found that if senior employees feel that they are discriminated at workplace for being too old, they may be less likely to provide knowledge to employees of younger generations, because in that case, these focal employees may become less identified with the organization. This study result gives managers the hint that in order to deal with talent shortage problem and to encourage senior employees to transfer knowledge to younger employees, managers may try to shape respecting perceptions on older employees, through either training or organizational culture building. For instance, organizations can train employees to think in the shoes of other employees from different ages. As [37] claimed, "age simulation-envisioning oneself in another age group - can ... facilitate inter-generational understanding and cooperation". In this way, when senior employee feel less discriminated, they may become more willing to engage in intergenerational knowledge transfer. In turn, the talent shortage problem could be largely relieved.

\subsection{Limitations and Future Directions}

Although our study makes important theoretical and practical contributions, it is subject to several limitations. Firstly, the study is conducted online, making it difficult for us to capture detailed portray of the respondents. When recruiting the respondents, we only ask them demographic information. But because we wanted to build better answering experience for participants and focus their time on most important questions, we did not go further into other information, such as companies, industries, cities, organizational size, etc. This defect makes the research less detailed, making us unable to analyze whether there is any difference among different companies or industries, regarding the main effect and mediating effect. Future research may do additional onsite studies, to concentrate the respondents in one company or one industry, making it easier to acquire detailed information of data collection background. Secondly, our study is cross-sectional. Our study investigated the causal relationship among perceived age discrimination, organizational identification, and intergenerational knowledge transfer intention. Thus a better way would be to conduct multi-wave research. However, since we recruit participants online, if asking them to fill questionnaire for 2 or 3 times and having weeks of intervals between each time, then we are very likely to be faced with the problem of high non-response rate and thus the non-response bias. In order to avoid this bias, we did not conduct multi-wave study online. Future research may try to replicate this study offline, and collect data in multi waves.

\section{Conclusion}

Facing the prominent age discrimination problem and talent shortage problem 
in workplace, this research studies how perceived age discrimination can influence IGKTI. The research found that perceived age discrimination is negatively related to IGKTI and that organizational identification plays a full mediating role in this negative relationship. The research would contribute theoretically to the current research of age discrimination and intergenerational knowledge transfer intention, filling the research gap of finding the relationship between them as well as the underlying mechanism. Hopefully, this research would also contribute to the current literature of OCB. Practically, this research will provide managers with insight to promote the intention for intergenerational knowledge transfer by senior employees, through building a more respectful working environment to them and reducing discrimination towards them. In this way, the research will help managers to deal with the talent shortage problem and to prepare talent pipeline by intergenerational knowledge transfer within the organization.

\section{Conflicts of Interest}

The author declares no conflicts of interest regarding the publication of this paper.

\section{References}

[1] Roy, M. (2016) Employers Are Facing the Worst Talent Shortage since 2007. https://www.shrm.org/resourcesandtools/hr-topics/talent-acquisition/pages/employ ers-facing-worst-talent-shortage-2007.aspx

[2] Chee, Y.P. (2017) The Role of Talent Management in Employee Retention. Tunku Abdul Rahman University, Kampar.

[3] Chatterjee, S., Nankervis, A. and Connell, J. (2014) Framing the Emerging Talent Crisis in India and China: A Human Capital Perspective. South Asian Journal of Human Resources Management, 1, 25-43. https://doi.org/10.1177/2322093714526658

[4] Calo, T.J. (2008) Talent Management in the Era of the Aging Workforce: The Critical Role of Knowledge Transfer. Public Personnel Management, 37, 403-416. https://doi.org/10.1177/009102600803700403

[5] Collings, D.G. and Mellahi, K. (2009) Strategic Talent Management: A Review and Research Agenda. Human Resource Management Review, 19, 304-313. https://doi.org/10.1016/j.hrmr.2009.04.001

[6] Burmeister, A. and Deller, J. (2016) Knowledge Retention from Older and Retiring Workers: What Do We Know, and Where Do We Go from Here? Work, Aging and Retirement, 2, 87-104. https://doi.org/10.1093/workar/waw002

[7] Yi, Y. and Feng, S. (2005) Elderly Age Discrimination and Elderly Social Network. Journal of China Elderly Study, 2, 271-273.

[8] Wu, F. (2008) Older People in the Eye of Younger People: An Investigation on Age Discrimination. Youth Study, 7, 24-29.

[9] Kunze, F., Boehm, S.A. and Bruch, H. (2011) Age Diversity, Age Discrimination Climate and Performance Consequences-A Cross Organizational Study. Journal of Organizational Behavior, 32, 264-290. https://doi.org/10.1002/job.698

[10] Griffin, B., Bayl-Smith, P. and Hesketh, B. (2016) The Longitudinal Effects of Per- 
ceived Age Discrimination on the Job Satisfaction and Work Withdrawal of Older Employees. Work, Aging and Retirement, 2, 415-427. https://doi.org/10.1093/workar/waw014

[11] Fevre, R., Grainger, H. and Brewer, R. (2011) Discrimination and Unfair Treatment in the Workplace. British Journal of Industrial Relations, 49, 207-235. https://doi.org/10.1111/j.1467-8543.2010.00798.x

[12] Cooke, F.L. (2005) HRM, Work and Employment in China. Routledge, London. https://doi.org/10.4324/9780203390702

[13] Lee, C.K. (2007) Against the Law: Labor Protests in China's Rustbelt and Sunbelt. University of California Press, Berkeley.

[14] Rabl, T. and Triana, M. (2013) How German Employees of Different Ages Conserve Resources: Perceived Age Discrimination and Affective Organizational Commitment. International Journal of Human Resource Management, 24, 3599-3612. https://doi.org/10.1080/09585192.2013.777936

[15] Cooke, F.L. (2011) Labour Market Disparities and Inequalities. Book Chapter In: Sheldon, P., Kim, S., Li, Y. and Warner, M., Eds., China's Changing Workplace: Dynamism, Diversity and Disparity, Routledge, Abingdon, 259-276.

[16] Mael, F. and Ashforth, B.E. (1992) Alumni and Their Alma Mater: A Partial Test of the Reformulated Model of Organizational Identification. Journal of Organizational Behavior, 13, 103-123. https://doi.org/10.1002/job.4030130202

[17] Noethen, D. (2011) Knowledge Transfer in Teams and Its Role for the Prevention of Knowledge Loss. Jacobs University, Bremen.

[18] Sabri, S.M., Haron, H., Jamil, N. and Ibrahim, E.N.M. (2014) A Conceptual Review on Technological Intergenerational Knowledge Transfer. Journal of Computers, $\mathbf{9}$, 654-667. https://doi.org/10.4304/jcp.9.3.654-667

[19] Wang, C., Zuo, M. and An, X. (2017) Differential Influences of Perceived Organizational Factors on Younger Employees' Participation in Offline and Online Intergenerational Knowledge Transfer. International Journal of Information Management, 37, 650-663. https://doi.org/10.1016/j.ijinfomgt.2017.06.003

[20] Adams, J.S. (1965) Inequity in Social Exchange. In: Berkowitz, L., Ed., Advances in Experimental Psychology, 2nd Edition, Academic Press, San Diego, 267-299. https://doi.org/10.1016/S0065-2601(08)60108-2

[21] Organ, D.W (1988) Organizational Citizenship Behavior: The Good Soldier Syndrome. Lexington Books, Lexington.

[22] Organ, D.W (1988) A Restatement of the Satisfaction-Performance Hypothesis. Journal of Management, 14, 547-557. https://doi.org/10.1177/014920638801400405

[23] Lovell, S.E., Kahn, A.S., Anton, J., Davidson, A., Dowling, E., Post, D. and Mason, C. (1999) Does Gender Affect the Link between Organizational Citizenship Behavior and Performance Evaluation? Sex Roles, 41, 469-478. https://doi.org/10.1023/A:1018883018719

[24] Inkpen, A.C. and Tsang, E.W.K. (2005) Social Capital, Networks, and Knowledge Transfer. The Academy of Management Review, 30, 146-165. https://doi.org/10.5465/amr.2005.15281445

[25] Tyler, T.R. and Blader, S.L. (2000) Cooperation in Groups: Procedural Justice, Social Identity, and Behavioral Engagement. Psychology Press, Philadelphia.

[26] Zhang, Y., Guo, Y. and Newman, A. (2017) Identity Judgments, Work Engagement and Organizational Citizenship Behavior: The Mediating Effects Based on Group Engagement Model. Tourism Management, 61, 190-197. 
https://doi.org/10.1016/j.tourman.2017.01.005

[27] Tajfel, H. and Turner, J.C. (1986) The Social Identity Theory of Intergroup Behaviour. In: Worchel, S. and Austin, W.G., Eds., Psychology of Intergroup Relations, Helson-Hall, Chicago, 7-24.

[28] Liu, L., Wei, K., Zhang, X., Wen, D., Gao, L. and Lei, J. (2018) The Current Status and a New Approach for Chinese Doctors to Obtain Medical Knowledge Using Social Media: A Study of WeChat. Wireless Communications and Mobile Computing, 2018, Article ID: 2329876. https://doi.org/10.1155/2018/2329876

[29] Zhang, X., Wen, D., Liang, J. and Lei, J. (2017) How the Public Uses Social Media WeChat to Obtain Health Information in China: A Survey Study. BMC Medical Informatics and Decision Making, 17, 66. https://doi.org/10.1186/s12911-017-0470-0

[30] Zhang, T., Cao, L. and Wang, W.Y. (2017) The Impact of Virtual Try-On Image Interaction Technology on Online Shoppers' Purchase Decision. In: Proceedings of the 8 th International Conference on E-Education, E-Business, E-Management and E-Learning, ACM, New York, 6-10. https://doi.org/10.1145/3026480.3026484

[31] Brislin, R.W. (1970) Back-Translation for Cross-Cultural Research. Journal of Cross-Cultural Psychology, 1, 185-216. https://doi.org/10.1177/135910457000100301

[32] Bock, G.W., Zmud, R.W., Kim, Y.G. and Lee, J.N. (2005) Behavioral Intention Formation in Knowledge Sharing: Examining the Roles of Extrinsic Motivators, Social-Psychological Forces, and Organizational Climate. MIS Quarterly, 29, 87-111. https://doi.org/10.2307/25148669

[33] Liu, Y. and DeFrank, R.S. (2013) Self-Interest and Knowledge-Sharing Intentions: The Impacts of Transformational Leadership Climate and HR Practices. The International Journal of Human Resource Management, 24, 1151-1164. https://doi.org/10.1080/09585192.2012.709186

[34] Han, S.H. (2018) The Antecedents and Dimensionality of Knowledge-Sharing Intention: An Empirical Study of RandD Engineers in a High-Performing IT Company. European Journal of Training and Development, 42, 125-142. https://doi.org/10.1108/EJTD-09-2017-0073

[35] Jiang, C. and Zuo, M. (2017) A Study on Senior Employees' Intergenerational Knowledge Transfer Intention: The Roles of Meaning in Life and Developmental Stage in Life. Journal of Business Economics, 311, 24-33.

[36] Baron, R.M. and Kenny, D.A. (1986) The Moderator-Mediator Variable Distinction in Social Psychological Research: Conceptual, Strategic, and Statistical Considerations. Journal of Personality and Social Psychology, 51, 1173.

https://doi.org/10.1037/0022-3514.51.6.1173

[37] Chen, X., Beveridge, A.J. and Fu, P.P. (2018) Put Yourself in Others' Age: How Age Simulation Facilitates Inter-Generational Cooperation. In: Academy of Management Proceedings, No. 1, Academy of Management, New York, 16250. https://doi.org/10.5465/AMBPP.2018.249 


\section{Appendix}

\section{Questionnaire for senior employees}

All your answers will be confidential. They will not be presented to anyone in your organization. They will not be used for business purpose.

\section{Part 1 Demographic Data}

1) Gender

2) Education

3) Age

4) Organizational Tenure: How long have you been in this organization? (Accumulated years)

5) Retired $(0=$ yes, $1=$ no. Filter question.)

6) Full-time $(0=$ yes, $1=$ no. Filter question $)$

7) Supervisor $(0=$ nonsupervisory, $1=$ supervisor $)$ : Are you a team leader/manager/executive in your organization?

8) Organizational type $(0=$ state-owned, $1=$ non-state-owned $)$

\section{Part 2 Perceived age discrimination}

1) I have sometimes been unfairly singled out because of my age.

2) I feel socially isolated because of my age.

3) I have fewer training opportunities than those who are younger than me.

4) I have fewer opportunities for promotion than those who are younger than me.

5) I am scrutinized more heavily in my performance evaluation than those who are younger than me.

6) Those who are younger than me are provided with better job-assignments.

\section{Part 3 Organizational identification}

1) When someone criticizes this organization, it feels like a personal insult.

2) I am very interested in what others think about the organization.

3) When I talk about this organization, I usually say "we" rather than "they".

4) This organization's successes are my successes.

5) When someone praises this organization, it feels like a personal compliment.

6) If a story in the media criticized the organization, I would feel embarrassed.

\section{Part 4 Intergenerational knowledge transfer intention}

1) I will share my work reports and official documents with younger employees of my organization more frequently in the future.

2) I will always provide my manuals, methodologies and models for younger employees of my organization.

3) I intend to share my experience or know-how from work with younger employees of my organization more frequently in the future.

4) I will always provide my know-where or know-whom at the request of younger of my organization employees.

5) I will try to share my expertise from my education or training with younger employees of my organization in a more effective way. 